\title{
Knowledge and Perception of Bajo Tribe Women on High-Risk Pregnancy
}

\author{
Fatmah Afrianty Gobel ${ }^{1 *}$, A. M. Multazam ${ }^{1}$, Andi Asrina ${ }^{1}$, Ella Andayanie ${ }^{1}$ \\ ${ }^{1}$ Public Health Faculty, Universitas Muslim Indonesia, Makassar, Indonesia \\ *Corresponding author. Email: fatmahafrianty.gobel@umi. ac.id
}

\begin{abstract}
Every day more than 830 mothers die from diseases related to pregnancy and childbirth, $99 \%$ of maternal mortality rate (MMR) occurs in developing countries and in poor communities. Risk factors for $75 \%$ of maternal deaths are caused by severe postpartum bleeding, postpartum infections, high blood pressure during pregnancy (eclampsia), prolonged / obstructed labor which caused by narrow pelvic, or the baby breech location. Maternal mortality rate in Indonesia is 305 which is the highest in ASEAN countries (SUPAS 2015). The aim of this research was to obtain indepth information about knowledge and perceptions of Bajo women towards high risk pregnancies, since one factor that often causes late delivery of labor in risky pregnancies is mother's lack of knowledge in recognizing risky pregnancies. This was a qualitative study with phenomenological approach, 13 Bajo women were interviewed during this research. Results shows that Bajo women did not consider that some characteristics of risky pregnancies as a problem which could be a danger sign of pregnancy and childbirth. They assumed that high blood pressure (eclampsia), mothers with small and short pelvic is a normal condition for pregnancy and labor and so that they could still give birth normally. Their perception is formed based on empirical experience that they see from their daily lives, where in their society there are some women who have risky pregnancy signs but still able to give birth normally without any troubles or experiencing significant health problems until now. Due to this society perception and lack of knowledge related to pregnancy risk factors, most of Bajo women still entrust "shaman" as their helper during pregnancy and childbirth compared to midwives or health workers. The active role of midwives in providing counseling and education to Bajo society is necessary to overcome this problem so that pregnant women could recognize and identify risky pregnancies better.
\end{abstract}

Keywords: risky pregnancy, Bajo tribe, knowledge, perception

\section{INTRODUCTION}

WHO data (2017), there are 830 maternal deaths every day due to complications of pregnancy and childbirth. The SDGs are targeting to reduce global maternal mortality from 216 per 100,000 in 2015 to $<70$ per 100,000 live births by 2030. Generally, maternal deaths can be prevented by medical intervention, it is necessary to increase access of pregnant women, childbirth and breastfeeding to quality health care facilities. In 2016, millions of global births were not assisted by health workers, only $78 \%$ of births were attended by trained personnel [1].

Indonesia's Health Profile in 2017 the percentage of maternity mothers assisted by health care facilities in Southeast Sulawesi Province in 2017 was only $60.35 \%$ relatively low compared to other provinces in Indonesia [2].

The maternal mortality rate in Pomalaa District is $3 \%$ and the infant mortality rate is $5 \%$. For the achievement of K1 of $80.9 \%$, K4 of $71.6 \%$, delivery by health workers $68.3 \%$, postpartum visits (KF3) $60.59 \%$ and neonatal visits (KN3) $60.59 \%$ [3].

\footnotetext{
Various maternal and child health efforts $(\mathrm{MCH})$ have been carried out to overcome the enormous difference between maternal mortality rates (MMR) and infant mortality rates (IMR) between developed and developing countries, such as in Indonesia. The effort was made to save the mother from the beginning of pregnancy until the postpartum period so that the pregnancy and childbirth can be passed safely and the baby is born in good health [4]. One of the causes of the still high maternal mortality rate (MMR) is because the community still believes in a culture that is detrimental to health, for example entrusting delivery assistance to shaman. Culture and health are very close, culture or culture can shape habits and responses to health and disease in society regardless of their level. Besides socioeconomic factors such as lack of husband support, low level of education and economic level of the family influence the lack of use of ANC which indirectly contributes to the high MMR and IMR. This is seen in the conditions of the Bajo tribe in the coastal region [5].
} 
An in-depth study on socio-cultural aspects is needed in order to find a solution so that all pregnant women, maternity mothers, post-partum mothers and neonates can and are willing to take advantage of $\mathrm{MCH}$ services in their villages, especially for the Bajo people who are still very minimal in using health care facilities.

\section{METHOD}

The research method used was qualitative research with a phenomenological approach, 13 (thirteen) Bajo women were interviewed during this study [6].

The informants in this study consisted of ordinary informants namely Bajo women and key informants namely village midwives and the wife of the chief of the village of Hakatutobu Pomalaa, conducted in-depth interviews. This research is part of a research funded by Kemenristekdikti which was carried out in the Bajo Pomalaa tribe community in September 21, 2019, which aims to explore in depth information related to the knowledge and perceptions of Bajo Pomalaa mothers regarding high risk pregnancy.

\section{RESULTS AND DISCUSSION}

Table 1. The Characteristics Research Subject

\begin{tabular}{|c|c|c|c|c|c|c|}
\hline No & Informant & Age & $\begin{array}{c}\text { Educatio } \\
n\end{array}$ & Profession & Information & $\begin{array}{l}\text { number } \\
\text { of } \\
\text { children }\end{array}$ \\
\hline 1 & $\begin{array}{l}\text { Mrs. Neni } \\
(\mathrm{Nn})\end{array}$ & 32 & $\begin{array}{l}\text { Elementa } \\
\text { ry school }\end{array}$ & $\begin{array}{l}\text { Mother hou } \\
\text { se stairs }\end{array}$ & Informant & 4 \\
\hline 2 & $\begin{array}{l}\text { Mrs. Ati S } \\
\text { (As) }\end{array}$ & 23 & $\begin{array}{l}\text { Middle } \\
\text { School }\end{array}$ & $\begin{array}{l}\text { Mother hou } \\
\text { se stairs }\end{array}$ & Informant & 2 \\
\hline 3 & $\begin{array}{l}\text { Mrs. Santi } \\
\text { (St) }\end{array}$ & 40 & $\begin{array}{l}\text { Elementa } \\
\text { ry school }\end{array}$ & $\begin{array}{l}\text { Mother hou } \\
\text { se stairs }\end{array}$ & Informant & 5 \\
\hline 4 & $\begin{array}{l}\text { Mrs. Lina } \\
\text { (Ln) }\end{array}$ & 22 & $\begin{array}{l}\text { Elementa } \\
\text { ry school }\end{array}$ & $\begin{array}{l}\text { Mother hou } \\
\text { se stairs }\end{array}$ & Informant & 3 \\
\hline 5 & $\begin{array}{l}\text { Mrs. Hasm } \\
\text { ia (Hs) }\end{array}$ & 25 & $\begin{array}{l}\text { Middle } \\
\text { School }\end{array}$ & $\begin{array}{l}\text { Mother hou } \\
\text { se stairs }\end{array}$ & Informant & 2 \\
\hline 6 & $\begin{array}{l}\text { Mrs. Nursi } \\
\text { a (Ns) }\end{array}$ & 43 & $\begin{array}{l}\text { Elementa } \\
\text { ry school }\end{array}$ & $\begin{array}{l}\text { Mother hou } \\
\text { se stairs }\end{array}$ & Informant & 5 \\
\hline 7 & $\begin{array}{l}\text { Mrs . Jumr } \\
\text { iani (Jm) }\end{array}$ & 21 & $\begin{array}{l}\text { Elementa } \\
\text { ry school }\end{array}$ & $\begin{array}{l}\text { Mother hou } \\
\text { se stairs }\end{array}$ & Informant & 3 \\
\hline 8 & $\begin{array}{l}\text { Mrs . Asla } \\
\text { mia (Am) }\end{array}$ & 35 & $\begin{array}{l}\text { Elementa } \\
\text { ry school }\end{array}$ & $\begin{array}{l}\text { Mother hou } \\
\text { se stairs }\end{array}$ & Informant & 6 \\
\hline 9 & $\begin{array}{l}\text { Mrs . Indar } \\
\text { e (In) }\end{array}$ & 53 & $\begin{array}{l}\text { Elementa } \\
\text { ry school }\end{array}$ & $\begin{array}{l}\text { Mother hou } \\
\text { se stairs }\end{array}$ & Informant & 7 \\
\hline $\begin{array}{l}1 \\
0\end{array}$ & $\begin{array}{l}\text { Ms. Yuni } \\
\text { (Bd. Yn) }\end{array}$ & 24 & $\begin{array}{l}\text { D3 Mid } \\
\text { wifery }\end{array}$ & Midwife & Informant & \\
\hline 11 & $\begin{array}{l}\text { Mrs. Yati } \\
(\mathrm{Yt})\end{array}$ & 47 & $\begin{array}{l}\text { Middle } \\
\text { School }\end{array}$ & $\begin{array}{l}\text { Mother ho } \\
\text { use stairs }\end{array}$ & $\begin{array}{l}\text { Key Infor } \\
\text { mant }\end{array}$ & 4 \\
\hline 12 & $\begin{array}{l}\text { Mrs. Irna } \\
\text { (Ir) }\end{array}$ & 48 & S1 & $\begin{array}{l}\text { Village M } \\
\text { other }\end{array}$ & $\begin{array}{l}\text { Key infor } \\
\text { mant }\end{array}$ & \\
\hline 13 & Eka (Ek) & 34 & $\begin{array}{l}\text { Middle } \\
\text { School }\end{array}$ & $\begin{array}{l}\text { Mother ho } \\
\text { use stairs }\end{array}$ & Informant & 6 \\
\hline
\end{tabular}

Table 1 shows the characteristics of the informants, generally Bajo women only work at home as housewives, with an average number of children more than 3 children, with primary and junior secondary education. The average Bajo mother married at a relatively young age, which is around the age of 14-15 years. With a fairly long reproduction period and a relatively low level of family planning participation, the birth rate and the number of children of the Bajo tribe are high.

Ali's research, 2017 revealed that for Bajo people education that should not be lost is a value taught from generation to generation, and this should not be lost from the lives of their children and grandchildren. While formal education is not considered important so it is enough to complete elementary school (SD) alone. Even if they continue their education to a higher level, they will maintain or preserve the value of education based on their local cultural wisdom [7].

According to La Manguntara research 2015, the numbers of school dropouts are caused by two main factors, namely internal factors and external factors. Internal factors related to the low interest and motivation of children for school as well as their erroneous perception of the meaning of education. External factors are closely related to the problem of parents' job as traditional fishermen [8].

Based on the results of in-depth interviews with Bajo women, it is generally said that conditions related to the possible signs, symptoms and causes of high-risk pregnancies are not a problem, as stated in the following interview.

It's okay if a pregnant woman is short in stature, it doesn't matter if the pregnant woman's blood pressure rises (Ek. 34, Am. 35, Nn. 32, Ln. 22 and Hs. 25)

They generally express their opinions based on what they see in the surrounding environment, as their statement follows.

There is a mother here who is pregnant with short stature and many of her children and she is in good health until now (As 23, Hs. 25, In. 53, St. 40). The midwife and wife of the village head of Hakatutobu has been providing education to Bajo tribal mothers about important matters to be considered to prevent risky pregnancies such as the following narrative.

We have routinely provided education to mothers here about pregnancy and childbirth, but the problem is that the people here are generally not in school so their knowledge is low, besides they also assume that these things are not a problem because they see directly from other mothers who have signs and symptoms of pregnancy are at risk but can still give birth normally (Ir. 48, Bd. Yn. 24).

The results showed that Bajo women did not consider some characteristics of risky pregnancy as a problem that could be a danger sign of pregnancy and childbirth. They assume that high blood pressure (eclampsia), mothers with small and short pelvis is a normal condition for pregnancy and childbirth so they can still give birth normally. Their perception is formed based on empirical experiences they see from everyday life, where in their society there are some women who have signs of a risky pregnancy but can still give birth normally without problems or experience significant health problems until now. Because of this public perception and lack of knowledge related to risk factors for pregnancy, most Bajo women still entrust "shamans" as their helpers during pregnancy and childbirth compared to midwives or health workers. 


\section{REFERENCES}

the characteristics are similar to the Bajo tribe, most of the most recent education respondents were Junior High School (SMP) $72.5 \%$, with the highest type of work being housewives $(50 \%)$, where knowledge was related to the beneficiaries of the source of output sea for health. People with low knowledge tend to use sea products less for health, whereas people with enough knowledge tend to use sea products for health Although the habits of the community have not been proven scientifically, the community believes and believes in the efficacy of marine products for health based on empirical experience from generation to generation [9].

Subardjan Research, 2017 women of childbearing age (1549) years of Bajo tribe in Wangi-Wangi Selatan District, Wakatobi Regency, the majority do not use contraceptive contraception, resulting in high fertility and the average number of Live Birth Children (ALH) and Living Children (ALH) AMH) tends to be higher [10].

Generally the Bajo people do not consider many children to be a risk factor for subsequent pregnancies. Therefore it is necessary to provide education to the public about the causes, symptoms and signs of pregnancy at risk. The active role of midwives in providing counseling and education to Bajo society is necessary to overcome this problem so that pregnant women could recognize and identify risky pregnancies better.

\section{CONCLUSION}

The results showed that Bajo women did not consider some characteristics of risky pregnancy as a problem that could be a danger sign of pregnancy and childbirth.

\section{ACKNOWLEDGMENT}

Thank you to the Ministry of Research, Technology and Higher Education, and the LP2S Universitas Muslim Indonesia for providing financial assistance for the implementation of this research activity
[1] World Health Organization, 2017, World Health Statistics 2017; Monitoring Health for The SDGs Sustainable Development Goals, Switzerland

[2] RI Ministry of Health, 2018, Indonesia Health Profile Data and Information 2017, Jakarta

[3] Pomalaa Health Center 2016, PWS-KIA Pomalaa Health Center 2015

[4] Center for Humanities, 2014. Health Policy and Community Empowerment, Jakarta.

[5] Gobel, Fatmah Afrianty, Andi Muhammad Multazam, Andi Asrina, Ella Andayanie, Socio-Cultural Aspects in the Selection of Childbirth Assistance in the Bajo Pomalaa Tribe of Southeast Sulawesi, 2018 National Proceedings Seminar on Multidisciplinary Synergy of Science and Technology, vol. 1, 2018, ISSN: 2622-0520, p. 322-325.

[6] Sugiyono. 2011. Quantitative, Qualitative, and R\&D Research Methods. Alfabeta Bandung.

[7] Ali, Mukti, 2017, Communicating Education and Preserving Bajo Local Wisdom, Inference, Journal of Religious Social Research, Vol 11, No. 1 (2017), p 187206

[8] La Mangutara, 2015, Strategy for Handling School Drop Outs in the Bajo Tribe Through Optimizing the Role of School Committees in Tiworo District Muna Regency, Etnoreflika, Volume 4 Number 3, October 2015

[9] Sudayasa, I Putu, Ratih Nurlyan Lawenga, 2016, Relationship of Knowledge and Attitudes with the Utilization of Marine Biological Resources for the Health of Coastal Communities in the District of Soropia, Medula, Scientific Journal of the Medical Faculty of Halu Oleo University, Volume 3 Number 2 April 2016, p. 273-281

[10] Subardjan, 2017, Family Planning and Fertility of the Bajo Tribe in a Changing Era (Case Study: Bajo Tribe in Mola Village, Wangi-Wangi Selatan District, Wakatobi Regency), MKG Vol. 18, No.1, June 2017 p. $40-53$ 